ARTICLE

https://doi.org/10.1038/s41467-020-14550-3

\title{
Mechanical rolling formation of interpenetrated lithium metal/lithium tin alloy foil for ultrahigh-rate battery anode
}

\author{
Mintao Wan', Sujin Kang², Li Wang ${ }^{3}$, Hyun-Wook Lee (i) ${ }^{2}$, Guangyuan Wesley Zheng ${ }^{4,5}$, Yi Cui i] ${ }^{6,7 \star}$ \& \\ Yongming Sun ${ }^{1 \star}$
}

To achieve good rate capability of lithium metal anodes for high-energy-density batteries, one fundamental challenge is the slow lithium diffusion at the interface. Here we report an interpenetrated, three-dimensional lithium metal/lithium tin alloy nanocomposite foil realized by a simple calendering and folding process of lithium and tin foils, and spontaneous alloying reactions. The strong affinity between the metallic lithium and lithium tin alloy as mixed electronic and ionic conducting networks, and their abundant interfaces enable ultrafast charger diffusion across the entire electrode. We demonstrate that a lithium/lithium tin alloy foil electrode sustains stable lithium stripping/plating under $30 \mathrm{~mA} \mathrm{~cm}^{-2}$ and $5 \mathrm{mAh} \mathrm{cm}^{-2}$ with a very low overpotential of $20 \mathrm{mV}$ for 200 cycles in a commercial carbonate electrolyte. Cycled under $6 \mathrm{C}$ ( $6.6 \mathrm{~mA} \mathrm{~cm}^{-2}$ ), a $1.0 \mathrm{mAh} \mathrm{cm}^{-2} \mathrm{LiNi}_{0.6} \mathrm{CO}_{0.2} \mathrm{Mnn}_{0.2} \mathrm{O}_{2}$ electrode maintains a substantial $74 \%$ of its capacity by pairing with such anode.

\footnotetext{
${ }^{1}$ Wuhan National Laboratory for Optoelectronics (WNLO), Huazhong University of Science and Technology (HUST), Wuhan, China. ${ }^{2}$ School of Energy and Chemical Engineering, Ulsan National Institute of Science and Technology (UNIST), 50 UNIST-gil, Ulsan 44919, Korea. ${ }^{3}$ Institute of Nuclear \& New Energy Technology, Tsinghua University, Beijing 100084, China. ${ }^{4}$ Institute of Materials Research and Engineering, A*STAR, 2 Fusionopolis Way, Innovis, Singapore 138634, Singapore. ${ }^{5}$ Department of Chemical and Biomolecular Engineering, National University of Singapore, 10 Kent Ridge Crescent, Singapore 119260 , Singapore. ${ }^{6}$ Department of Materials Science and Engineering, Stanford University, Stanford, CA 94305, USA. ${ }^{7}$ Stanford Institute for Materials and Energy Sciences, SLAC National Accelerator Laboratory, 2575 Sand Hill Road, Menlo Park, CA 94025, USA. *email: yicui@stanford.edu; yongmingsun@hust.edu.cn
} 
ithium-ion batteries (LIBs) based on intercalation chemistry with the combination of a lithium transition metal oxide (or phosphate) cathode and a graphite anode have been widely used in consumer electronics and are making their way to electric vehicles and grids ${ }^{1,2}$. However, these conventional LIBs are reaching the limits regarding energy and power density ${ }^{3-5}$. The development of rechargeable lithium-based batteries with much higher energy and power density is of vital importance for fast expanding their applications, which certainly relies on breakthroughs in materials and electrode design ${ }^{6,7}$. An effective approach is to search for high-capacity anode materials with low potential against cathode materials and high lithium-ion diffusion rate to replace the most widely used graphite material, which delivers a relatively low theoretical capacity of $372 \mathrm{mAh} \mathrm{g}^{-1}$ and slow lithium-ion diffusion rate $\left(10^{-12} \text { and } 10^{-6} \mathrm{~cm}^{2} \mathrm{~s}^{-1}\right)^{8}$. Lithium metal is a holy grail anode due to its high theoretical specific capacity ( $\left.3860 \mathrm{mAh} \mathrm{g}^{-1}\right)$ and low potential $(-3.040 \mathrm{~V}$ vs. standard hydrogen electrode). However, the practical application of lithium metal anode suffers from unsatisfactory cyclability, inferior rate capability and safety issues ${ }^{9-12}$. The high chemical reactivity makes lithium metal react with the liquid electrolyte to form an unstable solid-electrolyte interphase (SEI) layer. Such SEI layer breaks under considerable volume variation and repairs after the exposure of fresh lithium surface to the liquid electrolyte during cycling, leading to the continual consumption of active lithium and liquid electrolyte, and finally failure of the cell ${ }^{13,14}$. The slow lithium diffusion at the electrode/electrolyte interface may cause large overpotential under high current densities and therefore confine the rate capability of lithium metal anode. The infinite relative volume change of lithium metal electrode without a host material leads to the absence of the spatial control of lithium deposition and thereby the growth of lithium dendrites, and eventually causes safety concerns ${ }^{9,10}$.

Considerable effort has been devoted to tackling the challenges of lithium metal anodes, including electrolyte (e.g., fluorinecontaining additive ${ }^{15,16}$, self-healing electrostatic shield ${ }^{17}$, fluorinated electrolyte ${ }^{18}$, and high salt concentration ${ }^{19,20}$ ) and interface engineering (e.g., artificial SEI ${ }^{21,22}$, nanoscale interfacial layer ${ }^{23,24}$, and lithium alloy based films ${ }^{25,26}$ ) for stabilizing the interface between the electrode and electrolyte, use of solid electrolytes for preventing dendrite growth ${ }^{27,28}$, and design of stable scaffolds/ hosts for minimizing volume change ${ }^{29-33}$. These efforts effectively alleviated certain problems of lithium metal anode mainly under moderate/low current densities (e.g., $<3 \mathrm{~mA} \mathrm{~cm}^{-2}$ ). However, achieving high rate capability of lithium metal anode still remains challenging6,34. The issues of lithium metal anode are aggravated under high current densities and high areal capacities, resulting in more severe battery failures. Recently, lithium metal structural design with high electrolyte-accessible surface area showed improved rate capability by reducing the local currents ${ }^{30-32}$. However, the increased contact area with electrolytes may lead to severe side reactions and reduce the lifespan of batteries. To date, there have been few significant breakthroughs that enable longterm stable cycling of lithium metal anodes at high current densities (e.g., $>5 \mathrm{~mA} \mathrm{~cm}^{-2}$ ) and moderately high areal capacities (e.g., $>3 \mathrm{mAh} \mathrm{cm}^{-2}$ ) with acceptable overpotentials in commercial carbonate electrolytes.

High rate capability of electrodes requires fast lithium-ion diffusion kinetics ${ }^{34}$. Lithium-rich alloy (e.g., lithium zinc alloy and lithium indium alloy) and $\mathrm{Li}_{3} \mathrm{PO}_{4}$ phases have high lithiumion diffusion coefficients $\left(10 \times 10^{-8} \text { to } 10 \times 10^{-6} \mathrm{~cm}^{2} \mathrm{~s}^{-1}\right)^{35-38}$ and a surface layer of such phases on lithium metal has proved to be effective in improving lithium diffusion at the electrode/electrolyte interface ${ }^{21,25}$. However, high rate capability requires fast lithium-ion diffusion kinetics over the entire electrode, including both the surface and interior, which relies rational electrode design.

Here, we report a nanostructured lithium metal foil electrode with in situ formed three-dimensional (3D) interconnected metallic lithium and mixed electron and lithium-ion conductive lithium tin alloy $\left(\mathrm{Li}_{22} \mathrm{Sn}_{5}\right)$ integrated networks. The $3 \mathrm{D}$ nanostructured metallic lithium network acts as active lithium source of the electrode. The $3 \mathrm{D}$ nanostructured $\mathrm{Li}_{22} \mathrm{Sn}_{5}$ network keeps composition and structure invariant and acts as a "pathway" for lithium diffusion and electron conduction during the stripping and plating of metallic lithium. The strong affinity between the 3D metallic $\mathrm{Li}$ and $\mathrm{Li}_{22} \mathrm{Sn}_{5}$ networks, and their abundant interfaces enable small interface impedance and therefore ultrafast lithium diffusion at these $\mathrm{Li} / \mathrm{Li}_{22} \mathrm{Sn}_{5}$ interfaces. A moderate potential difference $(\sim 0.3 \mathrm{~V})$ between the $\mathrm{Li}_{22} \mathrm{Sn}_{5}$ and metallic lithium functions as the driving force for lithium diffusion within the entire electrode. As a result, the as-achieved $\mathrm{Li} / \mathrm{Li}_{22} \mathrm{Sn}_{5}$ nanocomposite delivered ultrahigh-rate capability and good stability for long-term lithium stripping/deposition cycling. Under an ultrahigh current density of $30 \mathrm{~mA} \mathrm{~cm}^{-2}$ and high areal capacity of $5 \mathrm{mAh} \mathrm{cm}^{-2}$, the $\mathrm{Li} / \mathrm{Li}_{22} \mathrm{Sn}_{5}$ nanocomposite sustained stable electrodeposition/ dissolution over 200 cycles with a very low overpotential of $20 \mathrm{mV}$ in a commercial carbonate electrolyte. Furthermore, by pairing with a $\mathrm{Li} / \mathrm{Li}_{22} \mathrm{Sn}_{5}$ anode, a substantial $74 \%$ of the capacity was maintained for a $1.0 \mathrm{mAh} \mathrm{cm}{ }^{-2} \mathrm{LiNi}_{0.6} \mathrm{Co}_{0.2} \mathrm{Mn}_{0.2} \mathrm{O}_{2}$ electrode cycled at $6 \mathrm{C}\left(6.6 \mathrm{~mA} \mathrm{~cm}{ }^{-2}\right)$. A Li/ $/ \mathrm{Li}_{22} \mathrm{Sn}_{5} \mid \mathrm{LiFePO}_{4}$ cell delivered a high specific capacity of $132 \mathrm{mAh} \mathrm{g}^{-1}$ at $5 \mathrm{C}\left(4 \mathrm{~mA} \mathrm{~cm}^{-2}\right)$ and showed stable and flat potential profiles with high-capacity retention of $91 \%$ for 500 cycles.

\section{Results}

Fabrication and characterizations of $\mathrm{Li} / \mathrm{Li}_{22} \mathrm{Sn}_{5}$ nanocomposite. The $\mathrm{Li} / \mathrm{Li}_{22} \mathrm{Sn}_{5}$ nanocomposite foil was realized by a facile calendaring and folding route, and a spontaneous alloying reaction between metallic lithium and tin at room temperature in an Ar-filled glove box (Fig. 1a). During the fabrication, a tin foil was first sandwiched between two lithium foils with designed $\mathrm{Li} / \mathrm{Sn}$ atomic ratio of $44 / 5,88 / 5$, or $110 / 5$, resulting in theoretical usable Li metal capacities of 656,1468 , or $1737 \mathrm{mAh} \mathrm{g}^{-1}$ at the whole $3 \mathrm{D}$ nanocomposite. After 15 times of folding and calendaring operation, the thickness of each metal layer would be reduced to as low as $\sim 5 \mathrm{~nm}$ in theory, producing periodically stacked metallic lithium and tin nanolayers with rich amount of $\mathrm{Li} / \mathrm{Sn}$ interfaces. The metallic lithium and tin reacted spontaneously at these freshly formed interfaces and produced an interpenetrated $3 \mathrm{D} \mathrm{Li} /$ $\mathrm{Li}_{22} \mathrm{Sn}_{5}$ nanocomposite foil $\left[(22+x) \mathrm{Li}+5 \mathrm{Sn} \rightarrow \mathrm{Li}_{22} \mathrm{Sn}_{5}+x \mathrm{Li}\right.$ (excess)], featuring 3D interconnected metallic lithium and $\mathrm{Li}_{22} \mathrm{Sn}_{5}$ integrated networks with strong affinity and abundant interfaces between metallic $\mathrm{Li}$ and $\mathrm{Li}_{22} \mathrm{Sn}_{5}$. Since the $\mathrm{Li} / \mathrm{Li}_{22} \mathrm{Sn}_{5}$ nanocomposite foils with $\mathrm{Li} / \mathrm{Sn}$ atomic ratios of $44 / 5$ and $88 /$ 5 showed same structure and very similar electrochemical performance (discussed in the next section), we performed the detailed materials and battery characterizations using the foil with $\mathrm{Li} / \mathrm{Sn}$ atomic ratio of $44 / 5$ as an example unless otherwise stated. The $\mathrm{Li} / \mathrm{Li}_{22} \mathrm{Sn}_{5}$ nanocomposite exhibits a foil structure (Fig. 1a, bottom right), similar to the initial metallic lithium and tin foils (Supplementary Fig. 1). The X-ray diffraction (XRD) results confirm the coexistence of the $\mathrm{Li}_{22} \mathrm{Sn}_{5}$ and metallic lithium phases in the as-achieved nanocomposite foil (Fig. 1b). The signals of metallic tin disappear in the XRD pattern of the resultant Li/ $\mathrm{Li}_{22} \mathrm{Sn}_{5}$ nanocomposite, indicating that all the initial metallic tin has converted to $\mathrm{Li}_{22} \mathrm{Sn}_{5}$. X-ray photoelectron spectroscopy (XPS) analyses were performed after Ar sputtering to reveal the surface electronic state of the elemental composition. Different from a 
a
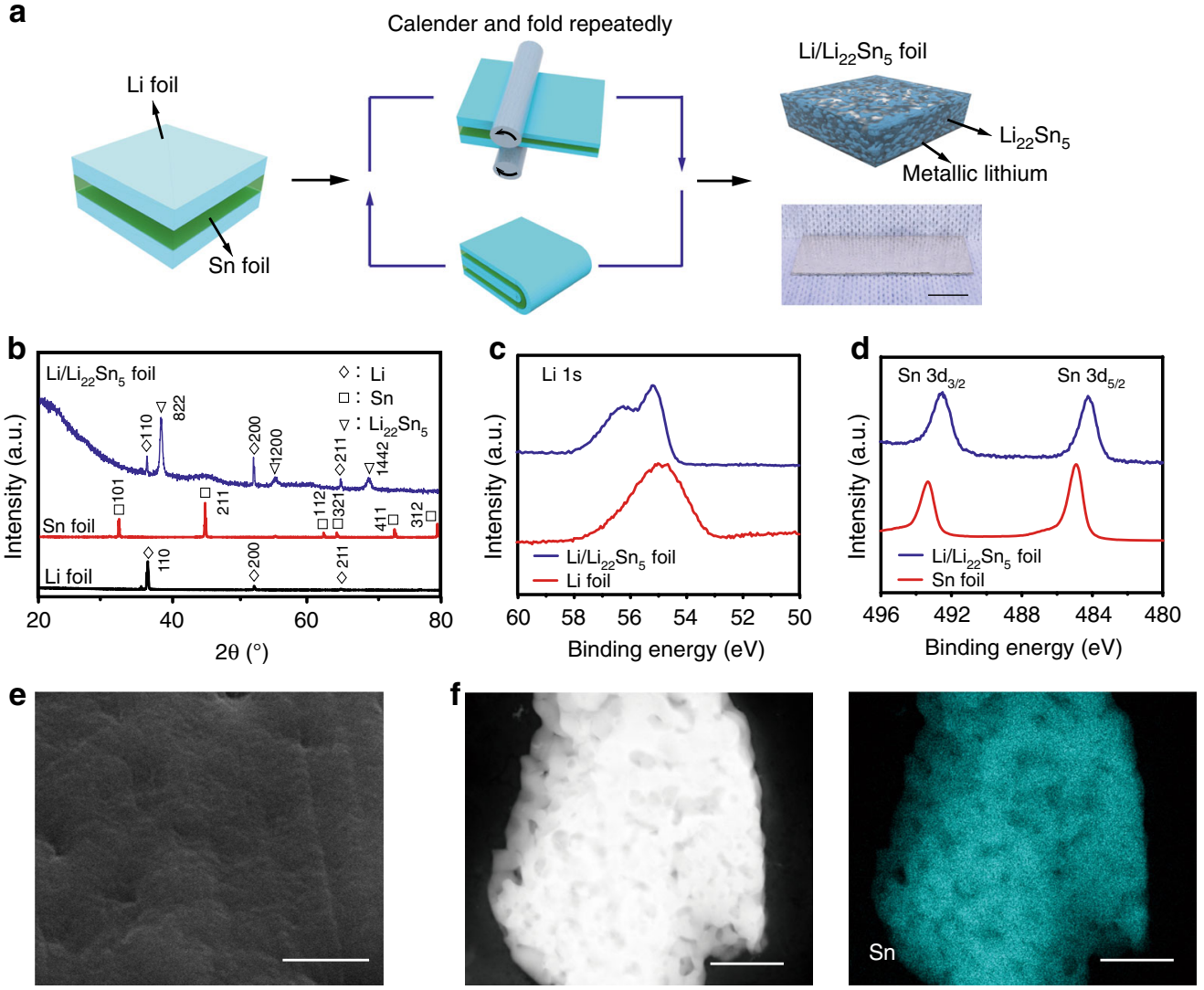

Fig. 1 Fabrication and characterizations of the $\mathbf{L i} / \mathbf{L i}_{\mathbf{2 2}} \mathbf{S n}_{\mathbf{5}}$ nanocomposite foil. a Schematic of the fabrication of the $\mathrm{Li} / \mathrm{Li}_{22} \mathrm{Sn} \mathrm{S}_{5}$ nanocomposite foil. Two pieces of $\mathrm{Li}$ metal foils and one piece of $\mathrm{Sn}$ foil were stacked together to form a Li-Sn-Li sandwich. Repeated calendaring and folding operations were performed for the Li-Sn-Li sandwich, producing periodically stacked metallic lithium and tin nanolayers with rich amount of Li/Sn interfaces. The metallic lithium and tin reacted spontaneously at these freshly formed interfaces, and formed a $\mathrm{Li} / \mathrm{Li}_{22} \mathrm{Sn}_{5}$ nanocomposite foil. The photo of the $\mathrm{Li} / \mathrm{Li}_{22} \mathrm{Sn}_{5}$ nanocomposite foil is shown in the bottom right (scale bar, $1 \mathrm{~cm}$ ). $\mathbf{b}$ X-ray diffraction (XRD) patterns of the starting Li foil, Sn foil and the as-fabricated $\mathrm{Li} / \mathrm{Li}_{22} \mathrm{Sn}_{5}$ foil. c, $\mathbf{d}$ High-resolution Li 1s (c) and Sn 3d (d) X-ray photoelectron spectroscopy (XPS) spectra for the pristine metallic Li foil, metallic Sn foil, and the $\mathrm{Li} / \mathrm{Li}_{22} \mathrm{Sn}_{5}$ foil after surface cleaning by sputtering. e Top view scanning electronic microscopy (SEM) image of the Li/Li $\mathrm{L}_{22} \mathrm{Sn} \mathrm{n}_{5}$ foil (scale bar, $1 \mu \mathrm{m}$ ). f Scanning transmission electron microscope (STEM) image of the $\mathrm{Li}_{22} \mathrm{Sn}_{5}$ and the corresponding energy dispersive X-Ray (EDX) elemental mapping image for $\mathrm{Sn}$ (scale bar, $500 \mathrm{~nm}$ ). After electrochemically stripping the metallic Li away, a three-dimensional (3D) interconnected $\mathrm{Li}_{22} \mathrm{Sn}_{5}$ framework was observed.

single characteristic peak at $55.0 \mathrm{eV}$ in the high-resolution $\mathrm{Li}$ $1 \mathrm{~s}$ spectrum for the pure lithium metal foil ${ }^{39}$, two distinct peaks at $55.2 \mathrm{eV}$ and $56.3 \mathrm{eV}$ were observed for the $\mathrm{Li} / \mathrm{Li}_{22} \mathrm{Sn}_{5}$ nanocomposite, the latter of which was ascribed to the lithium element in $\mathrm{Li}_{22} \mathrm{Sn}_{5}$ (Fig. 1c). In the high-resolution $\mathrm{Sn} 3 \mathrm{~d}$ spectra, the Sn $3 d_{5 / 2}$ and $3 d_{3 / 2}$ peaks at $484.9 \mathrm{eV}$ and $493.3 \mathrm{eV}$ for the pure metallic Sn foil ${ }^{40}$ shifted to $484.2 \mathrm{eV}$ and $492.6 \mathrm{eV}$ for the $\mathrm{Li} / \mathrm{Li}_{22} \mathrm{Sn}_{5}$ nanocomposite, respectively, indicating the transformation of metallic $\mathrm{Sn}$ to $\mathrm{Li}_{22} \mathrm{Sn}_{5}$ (Fig. 1d). Scanning electron microscopy (SEM) investigation was further performed to investigate the morphology and structure of the $\mathrm{Li} / \mathrm{Li}_{22} \mathrm{Sn}_{5}$ nanocomposite. The in situ formation of the $\mathrm{Li}_{22} \mathrm{Sn}_{5}$ network and its strong affinity with metallic $\mathrm{Li}$ make the $\mathrm{Li}_{22} \mathrm{Sn}_{5}$ network remain close contact with the metallic $\mathrm{Li}$ in the $\mathrm{Li} / \mathrm{Li}_{22} \mathrm{Sn}_{5}$ composite, leading to a dense structure of the $\mathrm{Li} / \mathrm{Li}_{22} \mathrm{Sn}_{5}$ composite foil (Fig. 1e). After electrochemically stripping away the metallic $\mathrm{Li}$, it was observed that the $\mathrm{Li}_{22} \mathrm{Sn}_{5}$ has the topology of interconnected networks with the dimension of $\sim 150 \mathrm{~nm}$ and numerous interconnected interspaces (Fig. 1f). Therefore, the asfabricated $\mathrm{Li} / \mathrm{Li}_{22} \mathrm{Sn}_{5}$ nanocomposite foil possesses a unique nanostructure with 3D interconnected metallic lithium and $\mathrm{Li}_{22} \mathrm{Sn}_{5}$ integrated networks. For a $\mathrm{Li} / \mathrm{Li}_{22} \mathrm{Sn}_{5}$ composite electrode with $10 \mathrm{mAh} \mathrm{cm}^{-2}$ of metallic $\mathrm{Li}$, the calculated contact area between the metallic $\mathrm{Li}$ and $\mathrm{Li}_{22} \mathrm{Sn}_{5}$ reaches 1759 or $2638 \mathrm{~cm}^{2}$, respectively, based on the geometry of nanowires or nanoparticles, which is three orders of magnitude higher than the accessible area to liquid electrolyte $\left(1 \mathrm{~cm}^{2}\right)$ in the conventional $\mathrm{Li}$ metal anode. Thus, the local current density for the metallic Li in the $\mathrm{Li} / \mathrm{Li}_{22} \mathrm{Sn}_{5}$ composite electrode can be greatly reduced in comparison to that of the conventional $\mathrm{Li}$ metal anode when same overall current density is applied.

Such unique nanostructure allows fast lithium diffusion over the entire electrode and enables stable lithium stripping/plating cycling under high current densities without lithium dendrite growth due to its multiple advantages: First, due to the high lithium-ion diffusion coefficient, strong lithium affinity and abundant interfaces to metallic lithium, the $3 \mathrm{D}$ nanostructured $\mathrm{Li}_{22} \mathrm{Sn}_{5}$ network forms an lithium diffusion "pathway" over the entire $\mathrm{Li} / \mathrm{Li}_{22} \mathrm{Sn}_{5}$ electrode. Metallic lithium can easily transport through such "pathway" back and forth. Meanwhile, the 3D nanostructured metallic lithium and $\mathrm{Li}_{22} \mathrm{Sn}_{5}$ networks both provide an electron "pathway" over the entire $\mathrm{Li} / \mathrm{Li}_{22} \mathrm{Sn}_{5}$ electrode. Second, the potential difference $(\sim 0.3 \mathrm{~V})$ between $\mathrm{Li}_{22} \mathrm{Sn}_{5}$ and metallic lithium can act as the driving force for lithium diffusion through such a "pathway". These advantages enable fast lithium diffusion over the entire the $\mathrm{Li} / \mathrm{Li}_{22} \mathrm{Sn}_{5}$ electrode, leading to good rate capability. Furthermore, fast lithium diffusion helps to alleviate the formation of lithium metal dendrites during cycling ${ }^{41}$ and thus improves the safety of rechargeable lithium metal 

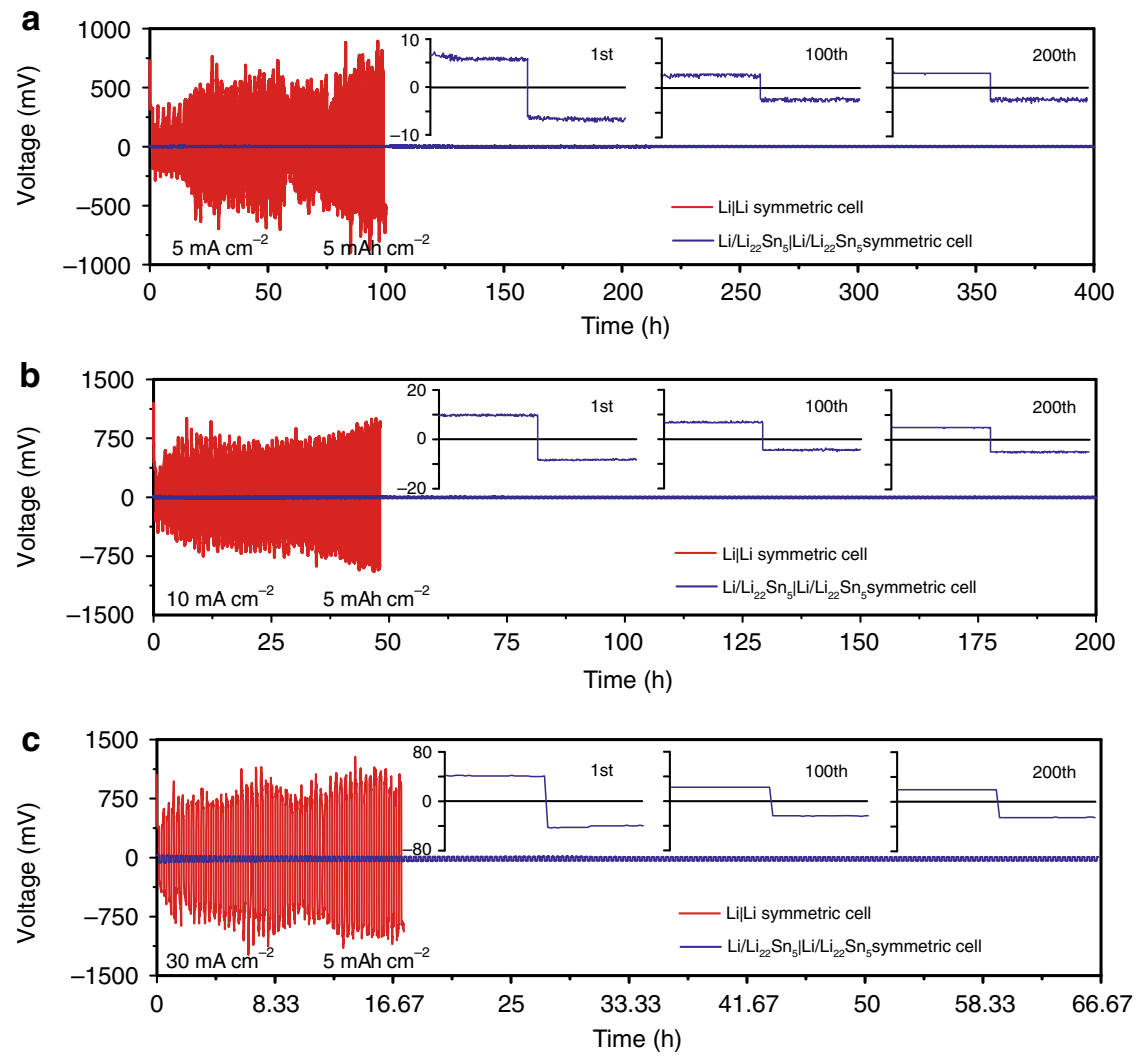

Fig. 2 Galvanostatic lithium plating/stripping cycling and voltage profiles of the $\mathbf{L i} / \mathbf{L i}_{\mathbf{2 2}} \mathbf{S n}_{\mathbf{5}} \mathbf{L} \mathbf{L i} / \mathbf{L i} \mathbf{i}_{\mathbf{2 2}} \mathbf{S n}_{\mathbf{5}}$ and $\mathbf{L i} \mid \mathbf{L i}$ symmetric cells. a-c Lithium stripping/ plating cycling of symmetric cells at $5 \mathrm{~mA} \mathrm{~cm}^{-2}(\mathbf{a}), 10 \mathrm{~mA} \mathrm{~cm}^{-2}(\mathbf{b})$ and $30 \mathrm{~mA} \mathrm{~cm}^{-2}$ (c) with areal capacity fixed at $5 \mathrm{mAh} \mathrm{cm}^{-2}$. The insets in (a-c) are the high-resolution voltage profiles of the $\mathrm{Li} / \mathrm{Li}_{22} \mathrm{Sn}_{5} / \mathrm{Li} / \mathrm{Li}_{22} \mathrm{Sn}_{5}$ symmetric cells at the specific cycle.

batteries. Third, the $\mathrm{Li}_{22} \mathrm{Sn}_{5}$ is less reactive with the liquid electrolyte than the metallic lithium due to its higher chemical potential. Thus, less electrolyte consumption and longer cycle life can be expected. Fourth, the $3 \mathrm{D}$ interconnected $\mathrm{Li}_{22} \mathrm{Sn}_{5}$ network remains invariant in the composition and structure on cycling and is capable of working as a stable host for stripping/plating of lithium metal and thus addressing the challenge of significant volume change.

Electrochemical performance of $\mathbf{L i} / \mathbf{L i}_{22} \mathrm{Sn}_{5}$ foils. To validate the advantages of the $\mathrm{Li} / \mathrm{Li}_{22} \mathrm{Sn}_{5}$ electrode for high-power-density lithium metal batteries, stripping/plating measurements were performed with a practical high areal capacity of lithium $\left(5 \mathrm{mAh} \mathrm{cm}^{-2}\right)$ at various high current densities $\left(5,10,20\right.$ and $\left.30 \mathrm{~mA} \mathrm{~cm}^{-2}\right)$ in symmetric cells using commercial carbonate-based electrolytes. Figure $2 \mathrm{a}$ shows the voltage profiles as a function of time for the $\mathrm{Li} / \mathrm{Li}_{22} \mathrm{Sn}_{5} \mid \mathrm{Li} / \mathrm{Li}_{22} \mathrm{Sn}_{5}$ symmetric cells and the $\mathrm{Li} \mid \mathrm{Li}$ counterparts for different cycles at $5 \mathrm{~mA} \mathrm{~cm}{ }^{-2}$ with fixed areal capacity of $5 \mathrm{mAh}$ $\mathrm{cm}^{-2}$. Supplementary Fig. 2 shows the enlarged voltage profiles of $\mathrm{Li} \mid \mathrm{Li}$ symmetric cells and Supplementary Figs. 3-5 show the enlarged voltage profiles of $\mathrm{Li} / \mathrm{Li}_{22} \mathrm{Sn}_{5} \mid \mathrm{Li} / \mathrm{Li}_{22} \mathrm{Sn}_{5}$ symmetric cells. For Li|Li symmetric cells cycled at $5 \mathrm{~mA} \mathrm{~cm}^{-2}$, a high overpotential of $0.65 \mathrm{~V}$ was observed at the beginning of the first cycle (Supplementary Fig. 2), corresponding to the difficulty of lithium stripping and growing beneath SEI at such a high current density. This overpotential decreased after the first cycle due to the increased real surface area caused by the growth of lithium dendrites. High overpotential was also observed at the end of each stripping/plating process after the 1st stripping process (Supplementary Fig. 2), corresponding to the usage of previously unused fresh lithium beneath the surface, which indicated the low Coulombic efficiency. Marked overpotential increase was observed after the second cycle, indicating the quick decay of the pristine lithium metal electrodes (Supplementary Fig. 2). The overpotential of $\mathrm{Li} \mid \mathrm{Li}$ symmetric cells fluctuated wildly over each striping/plating cycle. For example, the overpotential range was $0.35-0.75 \mathrm{~V}$ for the stripping process at the 14th cycle (Supplementary Fig. 2). In contrast, the $\mathrm{Li} / \mathrm{Li}_{22} \mathrm{Sn}_{5}$ electrode showed flat, stable, smooth voltage plateaus during lithium stripping/plating processes with a low, consistent overpotential and negligible fluctuation of $\sim 1 \mathrm{mV}$, as well as long-term stability for 200 cycles (Fig. 2a, Supplementary Figs. 3-5). Observed from the enlarged figures (Supplementary Figs. 2 and 4), the overpotential of the $\mathrm{Li} / \mathrm{Li}_{22} \mathrm{Sn}_{5} \mid \mathrm{Li} / \mathrm{Li}_{22} \mathrm{Sn}_{5}$ symmetric cell at the beginning of the first cycle was two order of magnitude lower than that of the $\mathrm{Li} \mid \mathrm{Li}$ symmetric cell $\left(\sim 8 \mathrm{mV}\right.$ for the $\mathrm{Li} / \mathrm{Li}_{22} \mathrm{Sn}_{5} \mid \mathrm{Li} / \mathrm{Li}_{22} \mathrm{Sn}_{5}$ symmetric cell vs. $0.65 \mathrm{~V}$ for the $\mathrm{Li} \mid \mathrm{Li}$ symmetric cell), indicating much better charge carrier transport through the entire $\mathrm{Li} / \mathrm{Li}_{22} \mathrm{Sn}_{5}$ electrode. The overpotential of the $\mathrm{Li} / \mathrm{Li}_{22} \mathrm{Sn}_{5}$ electrode further decreased and remained under $5 \mathrm{mV}$ after five cycles after the surface activation (Supplementary Fig. 4). Note that such low overpotential has never been reported in previous studies and it implies the significant role of the $3 \mathrm{D}$ nanostructured $\mathrm{Li}_{22} \mathrm{Sn}_{5}$ network in improving lithium diffusion over the entire electrode. Moreover, flat and stable stripping/plating plateaus with only $\sim 3 \mathrm{mV}$ overpotential were maintained at the 200th cycle (inset of Fig. 2a). Thus, the fast lithium diffusion kinetics of the $\mathrm{Li} / \mathrm{Li}_{22} \mathrm{Sn}_{5}$ electrode enables not only low potential hysteresis, but also flat and smooth cycling plateaus with a long lifespan. Supplementary Fig. 6 compared the Nyquist plots of $\mathrm{Li} \mid \mathrm{Li}$ and $\mathrm{Li} / \mathrm{Li}_{22} \mathrm{Sn}_{5} \mid \mathrm{Li}_{/} / \mathrm{Li}_{22} \mathrm{Sn}_{5}$ symmetric cells after different lithium stripping/plating cycles under $5 \mathrm{~mA} \mathrm{~cm}^{-2}$ with a fixed areal capacity of $5 \mathrm{mAh} \mathrm{cm}^{-2}$. The lithium foil electrode showed high interfacial resistance of $\sim 202 \Omega$ before cycling. It decreased to $\sim 46 \Omega$ after the 1 st cycle due to the broken native oxide layers and increased surface area caused by the growth of lithium dendrites. Then, it increased 
on cycling due to the accumulation of SEI and inactive lithium ${ }^{42}$. In contrast, the $\mathrm{Li} / \mathrm{Li}_{22} \mathrm{Sn}_{5}$ electrode had a much lower and more stable resistance during cycling. The value of interfacial resistance was $\sim 10 \Omega$ before cycling and remained only $\sim 1 \Omega$ after 10 cycles. This result supports the favorable charge carrier transport capability and stable interfacial properties of the $\mathrm{Li} / \mathrm{Li}_{22} \mathrm{Sn}_{5}$ electrode.

The potential of the $\mathrm{Li} / \mathrm{Li}_{22} \mathrm{Sn}_{5}$ anode for high power application was further proven by lithium stripping/plating measurements under larger current densities $\left(10,20\right.$ and $30 \mathrm{~mA} \mathrm{~cm}^{-2}$, Fig. $2 \mathrm{~b}, \mathrm{c}$ and Supplementary Figs. 7-15). The Li|Li symmetric cell could not sustain cycling under such high current densities, signaled by large voltage fluctuations (e.g., 0.5-1 V) (Fig. 2b, c). In sharp contrast, the $\mathrm{Li} / \mathrm{Li}_{22} \mathrm{Sn}_{5} \mid \mathrm{Li} / \mathrm{Li}_{22} \mathrm{Sn}_{5}$ symmetric cells exhibited significantly improved electrochemical performance. With the areal capacity fixed at $5 \mathrm{mAh} \mathrm{cm}^{-2}$, the overpotential of the $\mathrm{Li} / \mathrm{Li}_{22} \mathrm{Sn}_{5}$ foil electrode increased slightly from $8 \mathrm{mV}$ under $5 \mathrm{~mA} \mathrm{~cm}^{-2}, 10 \mathrm{mV}$ under $10 \mathrm{~mA} \mathrm{~cm}^{-2}$ to $20 \mathrm{mV}$ under $20 \mathrm{~mA} \mathrm{~cm}^{-2}$ and then to $40 \mathrm{mV}$ under $30 \mathrm{~mA} \mathrm{~cm}^{-2}$ during the initial stripping process (inset of Fig. 2 and Supplementary Fig. 11). Meanwhile, good longterm stability was achieved during the whole measurement process of 200 cycles under all the applied current densities for the $\mathrm{Li} / \mathrm{Li}_{22} \mathrm{Sn}_{5} \mid \mathrm{Li} / \mathrm{Li}_{22} \mathrm{Sn}_{5}$ symmetric cell (Fig. 2 and Supplementary Figs. 7-15). It is noted that $30 \mathrm{~mA} \mathrm{~cm}^{-2}$ is an unprecedented high current density in the measurements of lithium metal anodes, which has rarely been used, if any. The as-prepared $\mathrm{Li} / \mathrm{Li}_{22} \mathrm{Sn}_{5}$ electrode exhibited unprecedented low overpotential during the lithium stripping/plating measurement under such a high current. Moreover, continuous, smooth and plat voltage plateaus were maintained for 200 cycles for the $\mathrm{Li} / \mathrm{Li}_{22} \mathrm{Sn}_{5}$ electrode (Fig. 2c and Supplementary Figs. 14-16). During cycling under $30 \mathrm{~mA} \mathrm{~cm}^{-2}$, the overpotential of the $\mathrm{Li} / \mathrm{Li}_{22} \mathrm{Sn}_{5} \mid \mathrm{Li} / \mathrm{Li}_{22} \mathrm{Sn}_{5}$ symmetric cell slightly decreased from $40 \mathrm{mV}$ at the 1 st cycle, $30 \mathrm{mV}$ at the 10th cycle, $24 \mathrm{mV}$ at the 30 th cycle, to $20 \mathrm{mV}$ at the 50 th cycle, and remained at $20 \mathrm{mV}$ from 50 to 200 cycles (Fig. 2c and Supplementary Figs. 13-15). Importantly, under all applied current densities, the charge and discharge measurements of the symmetric $\mathrm{Li} / \mathrm{Li}_{22} \mathrm{Sn}_{5} \mid \mathrm{Li} / \mathrm{Li}_{22} \mathrm{Sn}_{5}$ cells were performed using commercial carbonate-based electrolytes with a high areal capacity of $5 \mathrm{mAh} \mathrm{cm}^{-2}$ manifesting its capability of working as high-power density and high-energy density battery anode. To the best of our knowledge, this is the best performance of lithium plating/stripping in lithium metal-based symmetric cells in consideration of applied current densities and areal capacities, compared with other Li metal studies by employing electrolyte and interface engineering, designing of stable hosts/scaffolds or using solid electrolyte ${ }^{15-32}$. Additionally, to investigate the effect of $\mathrm{Li} / \mathrm{Sn}$ atomic ratios on the electrochemical performance of the $\mathrm{Li} / \mathrm{Li}_{22} \mathrm{Sn}_{5}$ electrodes, we also tested the symmetric cells with higher $\mathrm{Li} / \mathrm{Sn}$ atomic ratios of $88 / 5$ and $110 / 5$, in addition to $44 / 5$ in the above discussion. With fixed areal capacity of $5 \mathrm{mAh} \mathrm{cm}^{-2}$ at $10 \mathrm{~mA} \mathrm{~cm}{ }^{-2}$, the $\mathrm{Li} / \mathrm{Li}_{22} \mathrm{Sn}_{5}$ electrode with a $\mathrm{Li} / \mathrm{Sn}$ atomic ratio of $88 / 5$ showed low initial overpotential $(14 \mathrm{mV}$ for the initial stripping process and $\sim 10 \mathrm{mV}$ on cycling) and stable cycling for 200 cycles (Supplementary Figs. 16-18), which was similar to the electrode with a $\mathrm{Li} / \mathrm{Sn}$ atomic ratio of $44 / 5$ (Supplementary Figs. 7-9). However, the electrode with a $\mathrm{Li} / \mathrm{Sn}$ atomic ratio of $110 / 5$ exhibited much larger overpotential than the counterparts with low $\mathrm{Li} / \mathrm{Sn}$ ratios and decayed within 10 cycles (Supplementary Fig. 19), since the $3 \mathrm{D}$ mixed conducting $\mathrm{Li}_{22} \mathrm{Sn}_{5}$ network could not form in the electrode due to the low content of Sn. Moreover, the lithium in the $\mathrm{Li} / \mathrm{Li}_{22} \mathrm{Sn}_{5}$ electrode could be fully extracted after 200 stripping/plating cycles at $30 \mathrm{~mA} \mathrm{~cm}^{-2}$ and $5 \mathrm{mAh} \mathrm{cm}^{-2}$ (Supplementary Fig. 21). The voltage rapidly reached $1 \mathrm{~V}$ after the exhaustion of all the stored lithium during the lithium extraction process. The sharp increase in voltage after the full stripping of metallic Li for the cycled electrode verified that short did not take place for the $\mathrm{Li} / \mathrm{Li}_{22} \mathrm{Sn}_{5} \mid \mathrm{Li} / \mathrm{Li}_{22} \mathrm{Sn}_{5}$ cells after 200 cycles cycled at $30 \mathrm{~mA} \mathrm{~cm}^{-2}$ and $5 \mathrm{mAh} \mathrm{cm}^{-2}$, which meets the demand for high-power-density applications, such as drone.

To validate all these superiorities of the $\mathrm{Li} / \mathrm{Li}_{22} \mathrm{Sn}_{5}$ electrode for high-power and high-energy density lithium metal batteries, full cells were constructed by using $\mathrm{Li} / \mathrm{Li}_{22} \mathrm{Sn}_{5}$ anodes paired with $\mathrm{LiNi}_{0.6} \mathrm{Co}_{0.2} \mathrm{Mn}_{0.2} \mathrm{O}_{2}$ (NCM) and $\mathrm{LiFePO}_{4}$ (LFP) cathodes. The electrochemical measurement of $\mathrm{NCM} \mid \mathrm{Li} / \mathrm{Li}_{22} \mathrm{Sn}_{5}$ and $\mathrm{NCM} \mid \mathrm{Li}$ cells was performed at increasing current rates based on a theoretical specific capacity of $170 \mathrm{mAh} \mathrm{g}^{-1}$ for $\mathrm{NCM}$ and $\sim 6.5 \mathrm{mg} \mathrm{cm}^{-2}$ active mass loading (Fig. $3 \mathrm{a}-\mathrm{c}$ ). The NCM|Li/ $\mathrm{Li}_{22} \mathrm{Sn}_{5}$ cells delivered capacities of $167 \mathrm{mAh} \mathrm{g}^{-1}$ at $0.5 \mathrm{C}$, $163 \mathrm{mAh} \mathrm{g}^{-1}$ at $1 \mathrm{C}, 157 \mathrm{mAh} \mathrm{g}^{-1}$ at $2 \mathrm{C}, 141 \mathrm{mAh} \mathrm{g}^{-1}$ at $4 \mathrm{C}$, $123 \mathrm{mAh} \mathrm{g}^{-1}$ at $6 \mathrm{C}, 107 \mathrm{mAh} \mathrm{g}^{-1}$ at $8 \mathrm{C}$ and $90 \mathrm{mAh} \mathrm{g}^{-1}$ at $10 \mathrm{C}$ (Fig. 3a). With a capacity of $123 \mathrm{mAh} \mathrm{g}^{-1}$ at a high current density of $6 C\left(6.6 \mathrm{~mA} \mathrm{~cm}{ }^{-2}\right)$, such a NCM $\mid \mathrm{Li} / \mathrm{Li}_{22} \mathrm{Sn}_{5}$ cell can fill up $74 \%$ of its capacity within 10 mins, suggesting the good rate capability of the $\mathrm{Li} / \mathrm{Li}_{22} \mathrm{Sn}_{5}$ electrode. Similar rate capacities were achieved on five $\mathrm{NCM} \mid \mathrm{Li} / \mathrm{Li}_{22} \mathrm{Sn}_{5}$ cells, showing the repeatability (Supplementary Fig. 22). In comparison, the NCM|Li cell gave much lower capacities, especially at high rates. For example, the capacities of $\mathrm{NCM} \mid \mathrm{Li}$ cell were $163 \mathrm{mAhg}^{-1}$ at $0.5 C$, $136 \mathrm{mAh} \mathrm{g}^{-1}$ at $2 \mathrm{C}, 92 \mathrm{mAh} \mathrm{g}^{-1}$ at $6 \mathrm{C}$ and $40 \mathrm{mAh} \mathrm{g}^{-1}$ at $10 \mathrm{C}$ (Fig. 3a). Moreover, smaller voltage hysteresis and higher discharge voltage were observed for the NCM cell using Li/ $\mathrm{Li}_{22} \mathrm{Sn}_{5}$ anode compared to that using pristine $\mathrm{Li}$ metal anode at $6 C$ (Fig. 3b, c), in accordance with the voltage profiles of the symmetric cells (Fig. 2, Supplementary Figs. 2-5, and Supplementary Figs. 7-15). Impressively, $\mathrm{Li}_{4} \mathrm{Ti}_{5} \mathrm{O}_{12}$ (LTO) $\mid \mathrm{Li} / \mathrm{Li}_{22} \mathrm{Sn}_{5}$ cells exhibited a stable discharge capacity of $1 \mathrm{mAh} \mathrm{cm}^{-2}$ at $33.1 \mathrm{~mA} \mathrm{~cm}^{-2}(15 \mathrm{C})$, suggesting the good stability of the $\mathrm{Li} /$ $\mathrm{Li}_{22} \mathrm{Sn}_{5}$ electrode at ultrahigh current density (Supplementary Fig. 23). Full cells with high cathode mass loading (NCM, $\sim 23.7 \mathrm{mg} \mathrm{cm}^{-2}$ ) and low areal capacity ratio of negative to positive electrodes (N/P ratio, 3.75) were further built and their electrochemical performance was investigated. A $\mathrm{NCM} \mid \mathrm{Li} /$ $\mathrm{Li}_{22} \mathrm{Sn}_{5}$ full cell delivered an initial capacity of $3.33 \mathrm{mAh} \mathrm{cm}{ }^{-2}$ for the 1 st cycle and $2.80 \mathrm{mAh} \mathrm{cm}^{-2}$ for the 100th cycle at $4 \mathrm{~mA} \mathrm{~cm}^{-2}$, with a capacity retention of $84 \%$ (Fig. 3d, e). In contrast, a NCM $\mid \mathrm{Li}$ full cell with the same loading of electrodes displayed a slightly lower capacity of $3.04 \mathrm{mAh} \mathrm{cm}^{-2}$ for the $1 \mathrm{st}$ cycle and sustained a much smaller number of cycles (50 cycles, Fig. 3d, f).

Due to the good long-term cycling stability of LFP, LFP|Li/ $\mathrm{Li}_{22} \mathrm{Sn}_{5}$ cells were constructed to investigate the cycling stability of the $\mathrm{Li} / \mathrm{Li}_{22} \mathrm{Sn}_{5}$ electrode. With typical LFP mass loading of $\sim 5 \mathrm{mg} \mathrm{cm}^{-2}$, the $\mathrm{LFP} \mid \mathrm{Li} / \mathrm{Li}_{22} \mathrm{Sn}_{5}$ cell offered a high capacity of $132 \mathrm{mAh} \mathrm{g}^{-1}$ at a high rate of $5 \mathrm{C}\left(4 \mathrm{~mA} \mathrm{~cm}^{-2}\right)$ for the 1 st cycle and $120 \mathrm{mAh} \mathrm{g}^{-1}$ for the 500th cycle, delivering high-capacity retention of $91 \%$. Also, the capacity vs. cycle number profile of the $\mathrm{LFP} \mid \mathrm{Li} / \mathrm{Li}_{22} \mathrm{Sn}_{5}$ cell showed little fluctuation during cycling (Fig. 3g). As a contrast, LFP $\mid \mathrm{Li}$ cell displayed much lower capacity and obviously capacity decay on cycling (Fig. 3g). Its capacity was only $78 \mathrm{mAhg}^{-1}$ for the 500th cycle with its capacity retention of only $62 \%$. An in-depth comparison of voltage profiles for LFP cells paired with $\mathrm{Li} / \mathrm{Li}_{22} \mathrm{Sn}_{5}$ anode and $\mathrm{Li}$ metal anode was shown in Supplementary Fig. 21. As we prolonged the cycle number, the voltage profiles of the LFP|Li/ $\mathrm{Li}_{22} \mathrm{Sn}_{5}$ cell remained stable. Thus, the $\mathrm{Li} / \mathrm{Li}_{22} \mathrm{Sn}_{5}$ foil electrode is able to survive stable and extensive cycling. In contrast, the LFP $\mathrm{Li}$ cell showed an obvious increase in voltage hysteresis on cycling. Much smaller overpotential were observed for the LFP| $\mathrm{Li} / \mathrm{Li}_{22} \mathrm{Sn}_{5}$ cell at 1 st, 150th, and 300th cycle compared to LFP $\mid \mathrm{Li}$ cell (Supplementary Fig. 24). The remarkable electrochemical performance of the $\mathrm{NCM} \mid \mathrm{Li} / \mathrm{Li}_{22} \mathrm{Sn}_{5}$ and $\mathrm{LFP} \mid \mathrm{Li} / \mathrm{Li}_{22} \mathrm{Sn}_{5}$ cells 

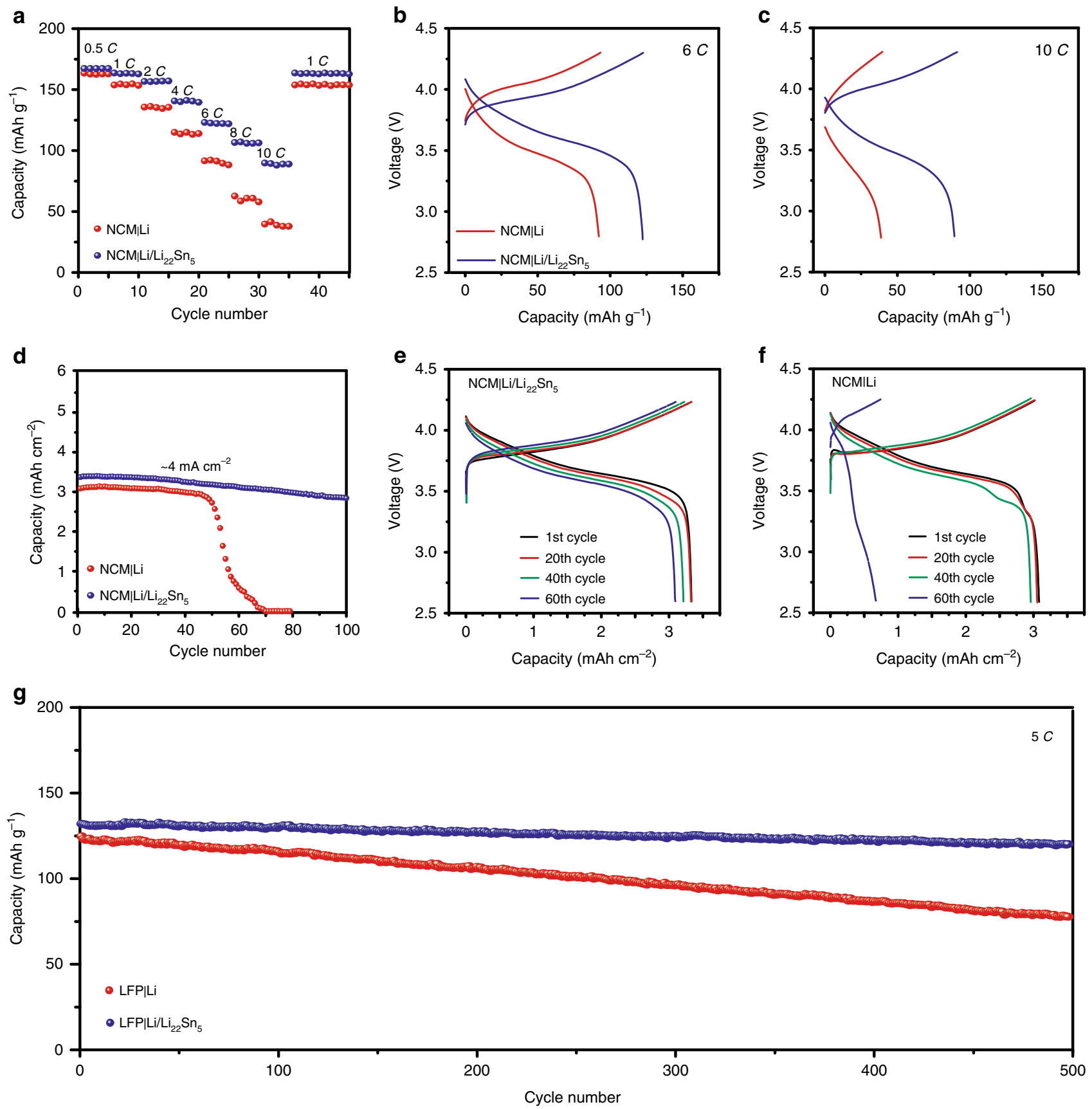

Fig. 3 Electrochemical performance of $\mathbf{L i N i}_{0.6} \mathrm{Co}_{\mathbf{0 . 2}} \mathbf{M n}_{\mathbf{0 . 2}} \mathbf{O}_{\mathbf{2}}(\mathbf{N C M}) \mid \mathrm{Li} / \mathrm{Li}_{\mathbf{2 2}} \mathrm{Sn}_{\mathbf{5}}$ and LiFePO $\mathbf{4}_{\mathbf{4}}(\mathbf{L F P}) \mid \mathbf{L i} / \mathrm{Li}_{\mathbf{2 2}} \mathrm{Sn}_{\mathbf{5}}$ cells. a Rate capability of the NCM|Li/ $\mathrm{Li}_{22} \mathrm{Sn}_{5}$ and NCM|Li cells with NCM loading of $\sim 6.5 \mathrm{mg} \mathrm{cm}^{-2}$ at various rates from 0.5 to $10 \mathbf{C}$. $\mathbf{b}$, c Voltage vs. capacity profile comparison of the NCM|Li/ $\mathrm{Li}_{22} \mathrm{Sn}_{5}$ and NCM|Li cells at rates of $6 \mathrm{C}(\mathbf{b})$ and $10 \mathrm{C}(\mathbf{c})$. d Capacity vs. cycle number profiles of the NCM|Li/Li ${ }_{22} \mathrm{Sn}_{5}$ and NCM|Li cells with high NCM mass loading $\left(23.7 \mathrm{mg} \mathrm{cm}^{-2}\right)$ and low areal capacity ratio of negative to positive electrodes (N/P ratio, 3.75). e, $\mathbf{f}$ Voltage vs. capacity profiles of the the NCMI $\mathrm{Li} / \mathrm{Li}_{22} \mathrm{Sn}_{5}(\mathbf{e})$ and NCM|Li (f) cells with high NCM mass loading and low N/P ratio for various cycles. $\mathbf{g}$ Capacity vs. cycle number profiles of the LFP|Li/ $\mathrm{Li}_{22} \mathrm{Sn}_{5}$ and LFP|Li cells with LFP mass loading of $\sim 5 \mathrm{mg} \mathrm{cm}^{-2}$ at $5 \mathrm{C}$ for 500 cycles.

further verifies the potential application of the $\mathrm{Li} / \mathrm{Li}_{22} \mathrm{Sn}_{5}$ anode in industrialized lithium metal batteries.

$\mathrm{Li}_{4} \mathrm{Ti}_{5} \mathrm{O}_{12}$ (LTO) can be an ideal $\mathrm{Li}$ reservoir to evaluate the Coulombic efficiency of a Li metal anode since it has near $100 \%$ Coulombic efficiency and does not provide Li during cycling. $10 \mathrm{mAh} \mathrm{cm}{ }^{-2} \mathrm{Li} / \mathrm{Li}_{22} \mathrm{Sn}_{5}$ electrode and pristine $\mathrm{Li}$ metal electrode were paired with $\sim 2.8 \mathrm{mAh} \mathrm{cm}^{-2}$ of LTO at $1.4 \mathrm{~mA} \mathrm{~cm}^{-2}(0.5 \mathrm{C})$ in a commercial carbonate electrolyte. The capacity of the LTO|Li cell started to quickly decay at the 30th cycle, showing a Coulombic efficiency of $91.2 \%$, and the LTO|Li cell lost all its capacity after 60 cycles (Supplementary Fig. 25a). In contrast, the capacity of the $\mathrm{LTO} \mid \mathrm{Li} / \mathrm{Li}_{22} \mathrm{Sn}_{5}$ cell remained constant $\left(\sim 155 \mathrm{mAh} \mathrm{g}^{-1}\right)$ for 75 cycles, giving a higher Coulombic efficiency of $96.5 \%$ (Supplementary Fig. 25a). Meanwhile, much smaller voltage hysteresis was also observed for the $\mathrm{LTO} \mid \mathrm{Li} / \mathrm{Li}_{22} \mathrm{Sn}_{5}$ cell in comparison to the $\mathrm{LTO} \mid \mathrm{Li}$ cell during cycling (Supplementary Fig. 25b, c).

Characterizations of Li stripping/plating. In situ optical microscopy and ex situ SEM characterizations were performed to investigate the lithium stripping and plating behavior of the $\mathrm{Li} / \mathrm{Li}_{22} \mathrm{Sn}_{5}$ nanocomposite foil. To directly monitor the lithium 
a
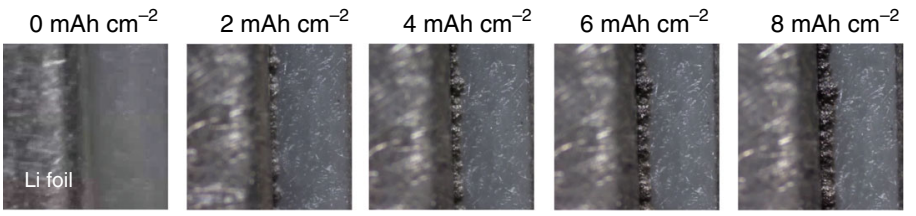

$10 \mathrm{mAh} \mathrm{cm}^{-2}$
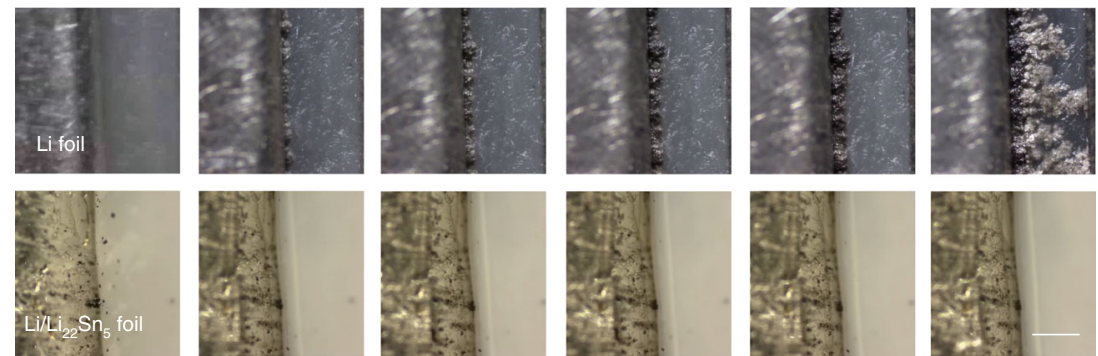

b
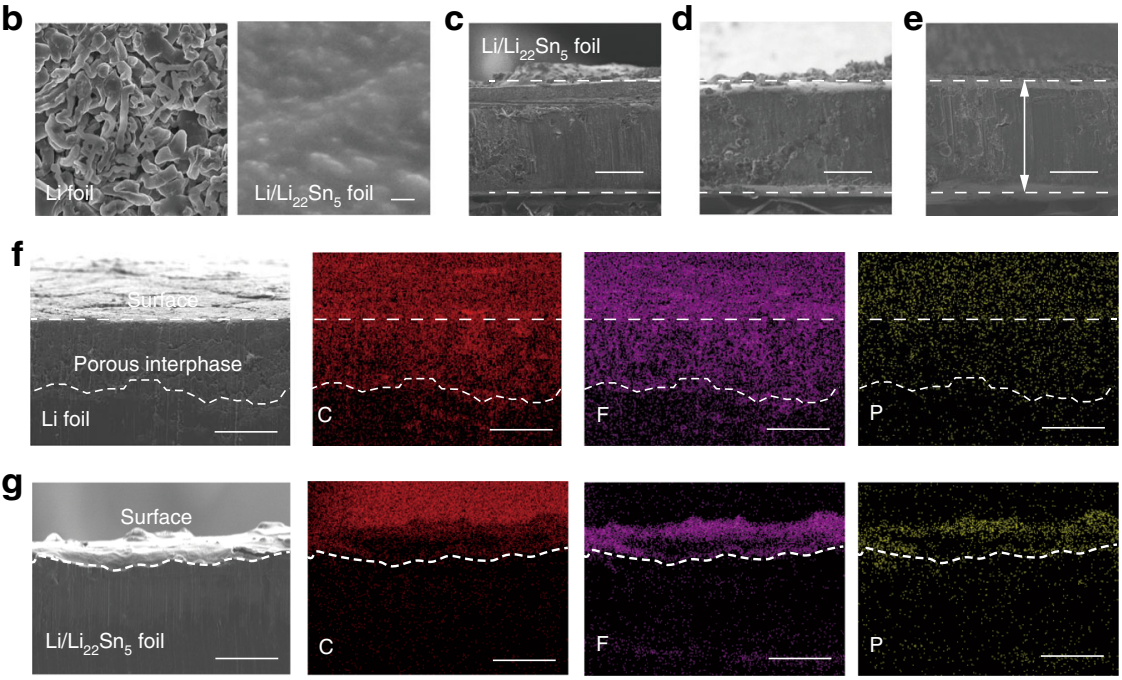

Fig. 4 Optical microscopy and SEM investigation of $\mathbf{L i} / \mathbf{L i}_{\mathbf{2 2}} \mathbf{S} \mathbf{S n}_{\mathbf{5}}$ electrode. a In situ optical microscopy investigation of the interfaces between the electrolyte and electrode for the $\mathrm{Li} \mid \mathrm{Li}$ (up) and $\mathrm{Li}_{2} \mathrm{Li}_{22} \mathrm{Sn}_{5} \mid \mathrm{Li}_{/} \mathrm{Li}_{22} \mathrm{Sn}_{5}$ (down) symmetric cells during lithium plating process $\left(1 \mathrm{~mA} \mathrm{~cm}^{-2}, 10 \mathrm{mAh} \mathrm{cm}^{-2}\right.$ ) (scale bar, $300 \mu \mathrm{m}$ ). b Top view SEM images of Li foil (left) and Li/Li $\mathrm{L}_{22} \mathrm{Sn}_{5}$ foil (right) after a stripping/plating cycle with $5 \mathrm{mAh} \mathrm{cm}^{-2}$ of lithium under $5 \mathrm{~mA} \mathrm{~cm}^{-2}$ (scale bar, $1 \mu \mathrm{m}$ ). c-e Cross-sectional SEM images of a Li/ $\mathrm{Li}_{22} \mathrm{Sn}_{5}$ foil before electrochemical lithium stripping/plating cycling (c), after stripping $10 \mathrm{mAh} \mathrm{cm}^{-2}$ of lithium under $5 \mathrm{~mA} \mathrm{~cm}^{-2}$ (d), and after a stripping/plating cycle with $10 \mathrm{mAh} \mathrm{cm}^{-2}$ of lithium under $5 \mathrm{~mA} \mathrm{~cm}{ }^{-2}(\mathbf{e})(\mathrm{scale} \mathrm{bar,}$ $200 \mu \mathrm{m}) . \mathbf{f}, \mathbf{g}$ Cross-sectional SEM images and the corresponding EDX mapping images of a Li foil (f) and a Li/Li $\mathrm{Li}_{22} \mathrm{Sn}_{5}$ foil (g) after 50 stripping/plating cycles with $5 \mathrm{mAh} \mathrm{cm}^{-2}$ of lithium under $5 \mathrm{~mA} \mathrm{~cm}^{-2}$ (scale bar, $50 \mu \mathrm{m}$ ).

plating process, transparent $\mathrm{Li} \mid \mathrm{Li}$ and $\mathrm{Li} / \mathrm{Li}_{22} \mathrm{Sn}_{5} \mid \mathrm{Li}_{2} / \mathrm{Li}_{22} \mathrm{Sn}_{5}$ symmetric cells were assembled and performed at $1 \mathrm{~mA} \mathrm{~cm}^{-2}$ under an optical microscope (Fig. 4a). The formation process of lithium dendrites on the bare lithium foil was clearly observed. These dendrites grew heterogeneously and some of them extended to more than $300 \mu \mathrm{m}$ in distance in the observed area after $10 \mathrm{~h}$. In contrast, the situation was very different for the $\mathrm{Li} / \mathrm{Li}_{22} \mathrm{Sn}_{5}$ electrode. There is no dendrite formation on the electrode surface even after $10 \mathrm{~h}$ ' plating of lithium metal at $1 \mathrm{~mA} \mathrm{~cm}^{-2}$. Slight movement of the electrode/electrolyte interface was observed due to the uniform lithium plating. Figure $4 \mathrm{~b}$ compared top-view SEM images of the pristine Li metal electrode and $\mathrm{Li} / \mathrm{Li}_{22} \mathrm{Sn}_{5}$ electrode after a stripping/plating cycle with $5 \mathrm{mAh} \mathrm{cm}^{-2}$ of lithium under $5 \mathrm{~mA} \mathrm{~cm}^{-2}$. A large amount of lithium dendrites was observed on the lithium foil surface (Fig. $4 \mathrm{~b}$ left), while a smooth surface was maintained for the $\mathrm{Li} / \mathrm{Li}_{22} \mathrm{Sn}_{5}$ foil due to the fast lithium diffusion, and uniform stripping and plating of lithium metal (Fig. $4 \mathrm{~b}$ right). Therefore, the $\mathrm{Li} / \mathrm{Li}_{22} \mathrm{Sn}_{5}$ nanocomposite foil is capable of working stably without dendrite growth and structural change. Previously, successful examples of surface modification and engineering were shown to suppress the growth of lithium dendrites ${ }^{21-26}$. In this work, we alleviate the formation of lithium metal dendrites and improve the safety of rechargeable lithium metal batteries through improving the lithium diffusion over the entire electrode by the in situ formed 3D nanostructured mixed conducting $\mathrm{Li}_{22} \mathrm{Sn}_{5}$ framework.
Volume stability of the $\mathrm{Li} / \mathrm{Li}_{22} \mathrm{Sn}_{5}$ foil was investigated through thickness measurement after lithium stripping/plating cycles. It was observed that the thickness of the $\mathrm{Li} / \mathrm{Li}_{22} \mathrm{Sn}_{5}$ foil did not change obviously before electrochemical lithium stripping (Fig. 4c), after stripping $10 \mathrm{mAh} \mathrm{cm}^{-2}$ of lithium under $5 \mathrm{~mA} \mathrm{~cm}^{-2}$ (Fig. 4d), and after a stripping/plating cycle with $10 \mathrm{mAh} \mathrm{cm}^{-2}$ of lithium under $5 \mathrm{~mA} \mathrm{~cm}^{-2}$ (Fig. 4e). The negligible thickness change for the $\mathrm{Li} / \mathrm{Li}_{22} \mathrm{Sn}_{5}$ electrode confirms that the $\mathrm{Li}_{22} \mathrm{Sn}_{5}$ framework works effectively as a stable skeleton, which guarantees the uniform lithium plating and stripping, and avoids the growth of lithium dendrites on the electrode surface during cycling. Moreover, the top-view SEM images do not show obvious pore structure or the exposure of the $\mathrm{Li}_{22} \mathrm{Sn}_{5}$ matrix for the $\mathrm{Li} / \mathrm{Li}_{22} \mathrm{Sn}_{5}$ foil after stripping $5 \mathrm{mAh} \mathrm{cm}^{-2}$ of lithium under $5 \mathrm{~mA} \mathrm{~cm}^{-2}$ (Supplementary Fig. 28). This result supports that the lithium stripping processes take place over the entire $\mathrm{Li} / \mathrm{Li}_{22} \mathrm{Sn}_{5}$ electrode, not only the surface, because of the lithium diffusion and electron transfer "pathway" provided by the $3 \mathrm{D} \mathrm{Li}_{22} \mathrm{Sn}_{5}$ network and the driving force for lithium diffusion provided by the potential difference between $\mathrm{Li}_{22} \mathrm{Sn}_{5}$ and metallic lithium. The $3 \mathrm{D} \mathrm{Li}_{22} \mathrm{Sn}_{5}$ nanostructured network remains close contact with the metallic lithium due to the good lithium affinity ${ }^{43}$, and keeps lithium ion and electron conductive on the whole lithium stripping/plating cycling. Meanwhile, the 3D metallic lithium nanostructured network provides good electron conductivity over the entire Li/ $\mathrm{Li}_{22} \mathrm{Sn}_{5}$ electrode. 
a

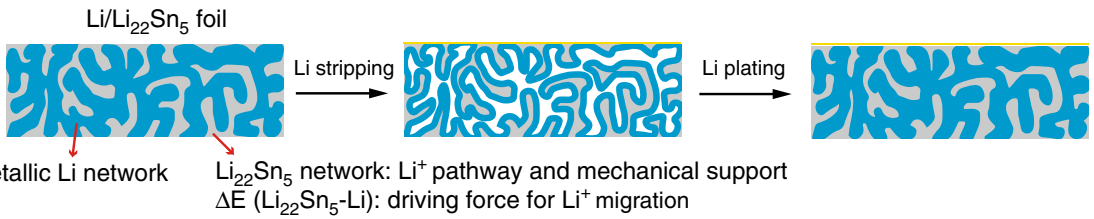

b
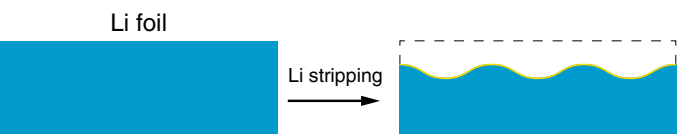

Li plating

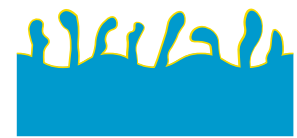

C

$\mathrm{Li} / 3 \mathrm{D}$ matrix foil
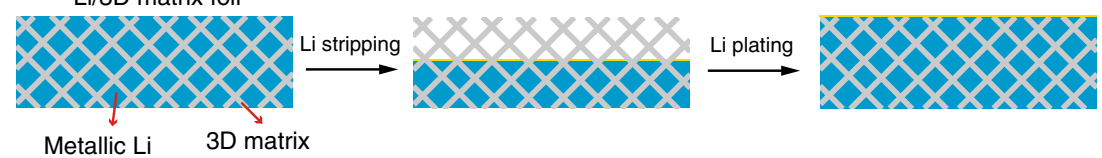

Fig. 5 Schematic of lithium stripping/plating process of $\mathrm{Li} / \mathrm{Li}_{22} \mathrm{Sn}_{5}$ nanocomposite foil, lithium foil, and Li metal with 3D matrix (Li/3D matrix). In the $\mathrm{Li} / \mathrm{Li}_{22} \mathrm{Sn}_{5}$ foil, the in situ formed nanostructured $3 \mathrm{D} \mathrm{Li}{ }_{22} \mathrm{Sn}_{5}$ and metallic lithium network interconnect with each to form an integrated structure with abundant $\mathrm{Li} / \mathrm{Li}_{22} \mathrm{Sn}_{5}$ interfaces with low interface impedance due to the good affinity between $\mathrm{Li}_{22} \mathrm{Sn}_{5}$ and metallic lithium. The $3 \mathrm{D}$ Li ${ }_{22} \mathrm{Sn}_{5} \mathrm{network}$ works as a lithium diffusion and electron transfer "pathway" and its potential difference with metallic lithium provides the driving force for lithium diffusion. Thus, the stripping and plating of metallic lithium metal takes place over the entire $\mathrm{Li}_{\mathrm{L}} \mathrm{Li}_{22} \mathrm{Sn}_{5}$ electrode (a). The pristine lithium metal foil electrode shows inhomogeneous lithium stripping and plating behavior and dendrite growth takes place during cycling (b). For the Li metal anode with "non-lithium ion conductive" 3D matrixes, the dissolution of lithium metal starts on the top or surface of the composite electrode during the lithium stripping process. Metallic lithium deposits back into the 3D porous structure during the lithium plating process (c).

To verify the different lithium stripping and plating behaviors of the bare $\mathrm{Li}$ metal and $\mathrm{Li} / \mathrm{Li}_{22} \mathrm{Sn}_{5}$ electrodes, the structure of the two electrodes were investigated after 50 cycles of lithium stripping/ plating at $5 \mathrm{~mA} \mathrm{~cm}^{-2}$ and $5 \mathrm{mAh} \mathrm{cm}^{-2}$. The cross-section SEM image of the bare Li metal electrode shows a porous and loose interphase layer with the thickness of $\sim 100 \mu \mathrm{m}$ above the dense pristine Li metal layer and the corresponding energy dispersive $\mathrm{X}$-Ray (EDX) elemental mapping images exhibit strong signals of $\mathrm{C}, \mathrm{F}$, and $\mathrm{P}$ elements on the surface layer and weak signals on the bottom layer (Fig. 4f). This result indicates that the SEI layer and electrolyte ( $\mathrm{LiPF}_{6}$ based carbonate liquid electrolyte) extend within the structure as cycling takes place. The formation of this loose interphase consumes active lithium and electrolyte, suggesting the serious corrosion of the bulk Li metal electrode. In contrast, the $\mathrm{Li} / \mathrm{Li}_{22} \mathrm{Sn}_{5}$ electrode preserves its dense structure and the signals of $\mathrm{C}, \mathrm{F}$, and $\mathrm{P}$ elements are very weak over the entire cross section (Fig. $4 \mathrm{~g}$ ). Therefore, the SEI layer of the $\mathrm{Li} / \mathrm{Li}_{22} \mathrm{Sn}_{5}$ electrode mainly remains fixed in place on top of the electrode and the $\mathrm{Li} / \mathrm{Li}_{22} \mathrm{Sn}_{5}$ electrode excludes the electrolyte from within the electrode during cycling. The schematic of the lithium stripping and plating process of the $\mathrm{Li} / \mathrm{Li}{ }_{22} \mathrm{Sn}_{5}$ electrode is shown in Fig. $5 \mathrm{a}$. Such lithium stripping and plating process differs from the bare lithium metal foil electrode, which shows inhomogeneous stripping and plating of lithium (Fig. 5b). Also, our design here is significantly different from previous reports on lithium metal anodes using a "non-lithium ion conductive" 3D matrixes (e.g., reduced graphene oxide ${ }^{30}$, carbon nanofiber ${ }^{44}$, and nickel foam ${ }^{45}$ ). Although the volume change at the electrode level would be reduced by using these mechanical supports, side reactions between the electrolyte and electrode would be enhanced due to the movement of electrode/electrolyte interface (Fig. 5c). Meanwhile, these electrodes with "non-lithium ion conductive" 3D matrixes cannot sustain cycling under high current densities, since the lithium diffusion within these electrodes is still limited.

\section{Discussion}

In this work, we demonstrated that, a unique nanostructured lithium metal electrode with 3D interconnected metallic lithium and $\mathrm{Li}_{22} \mathrm{Sn}_{5}$ integrated networks, generated by the spontaneous reaction between periodically stacked nanolayers of metallic lithium and tin, enabled stable lithium stripping/plating cycling under ultrahigh current densities. Due to the high lithium-ion diffusion coefficient, good lithium affinity and moderately potential difference between $\mathrm{Li}_{22} \mathrm{Sn}_{5}$ and metallic lithium, the $3 \mathrm{D}$ nanostructured $\mathrm{Li}_{22} \mathrm{Sn}_{5}$ network, where metallic lithium closely contacts, provides a pathway and driving force for fast lithium diffusion over the entire $\mathrm{Li} / \mathrm{Li}_{22} \mathrm{Sn}_{5}$ electrode. Also, such $3 \mathrm{D}$ nanostructured $\mathrm{Li}_{22} \mathrm{Sn}_{5}$ network enables fast electron transfer and functions as a stable host to minimize the volume change during lithium stripping and plating processes. It is worthwhile that our design here is significantly different from surface engineering with lithium conductive layer on pristine lithium foil or 3D inert mechanical support in previous studies. Lithium diffuses rapidly over the whole $\mathrm{Li} / \mathrm{Li}_{22} \mathrm{Sn}_{5}$ electrode through the rich amount of $\mathrm{Li} / \mathrm{Li}_{22} \mathrm{Sn}_{5}$ interfaces and 3D Li ${ }_{22} \mathrm{Sn}_{5}$ network. The $\mathrm{Li} / \mathrm{Li}_{22} \mathrm{Sn}_{5} / \mathrm{Li} /$ $\mathrm{Li}_{22} \mathrm{Sn}_{5}$ symmetric cell showed stable lithium stripping/plating cycling under $30 \mathrm{~mA} \mathrm{~cm}^{-2}$ at $5 \mathrm{mAh} \mathrm{cm}^{-2}$ for 200 cycles. A substantial $74 \%$ of the capacity was maintained for a $1.0 \mathrm{mAh} \mathrm{cm}$ ${ }^{-2} \mathrm{NCM}$ electrode cycled at $6 \mathrm{C}\left(6.6 \mathrm{~mA} \mathrm{~cm}^{-2}\right)$ by pairing such a $\mathrm{Li} / \mathrm{Li}_{22} \mathrm{Sn}_{5}$ anode. High capacity retention of $91 \%$ and stable potential profiles were achieved for an $\mathrm{LFP} \mid \mathrm{Li} / \mathrm{Li}_{22} \mathrm{Sn}_{5}$ cell for 500 cycles at $5 \mathrm{C}\left(4 \mathrm{~mA} \mathrm{~cm}^{-2}\right)$. These results suggest the potential application of $\mathrm{Li} / \mathrm{Li}_{22} \mathrm{Sn}_{5}$ nanostructured electrode in lithium metal batteries with high power and long lifespan.

\section{Methods}

Materials synthesis. The fabrication of the $\mathrm{Li} / \mathrm{Li}_{22} \mathrm{Sn}_{5}$ foil was realized using a repeated folding and calendaring method, and a spontaneous reaction between metallic lithium and tin. A tin foil and two lithium foils with same size and designed ratio of $\mathrm{Li} / \mathrm{Sn}$ were first stacked to form a $\mathrm{Li}-\mathrm{Sn}-\mathrm{Li}$ "sandwich" and pressed together by mechanical rolling using a roll squeezer in an Ar-filled glove box. The overall thickness of the produced $\mathrm{Li}-\mathrm{Sn}-\mathrm{Li}$ foil was $0.5 \mathrm{~mm}$, which could be changed by tuning the spacing between the two rollers of the roll squeezer. The $\mathrm{Li}-\mathrm{Sn}-\mathrm{Li}$ "sandwich" was folded and rolled repeatedly, which led to the gradual increase in the number and reduction in the thickness of each metal layer. Such process produced rich amount of fresh $\mathrm{Li} / \mathrm{Sn}$ interfaces, where the metallic lithium and tin reacted spontaneously, and formed a $3 \mathrm{D} \mathrm{Li}_{22} \mathrm{Sn}_{5}$ framework with excess lithium evenly embedded in $\left[(22+x) \mathrm{Li}+5 \mathrm{Sn} \rightarrow \mathrm{Li}_{22} \mathrm{Sn}_{5}+x \mathrm{Li}\right.$ (excess)]. The asachieved $\mathrm{Li} / \mathrm{Li}_{22} \mathrm{Sn}_{5}$ foil was cut into $12-\mathrm{mm}$-diameter electrodes for electrochemical measurements. 
Characterization. The morphology, microstructure, and component of the $\mathrm{Li} /$ $\mathrm{Li}_{22} \mathrm{Sn}_{5}$ foil were investigated using XRD (PANalytical B.V., Holland), fieldemission scanning electrode microscopy (FESEM, Sirion 200), X-ray photoelectron spectroscopy (XPS, VG Multilab 2000) and transmission electron microscopy (TEM, Talos F200X). Before the XRD measurement, samples were loaded on a glass slide and covered with Kapton tape in the Ar-filled glove box to avoid the reactions between the samples and ambient air. Samples for SEM, XPS, and TEM measurements were sealed in the Ar-filled glove box before being transferred into the chamber of the equipment. To observe the $\mathrm{Li}_{22} \mathrm{Sn}_{5}$ framework of the $\mathrm{Li} / \mathrm{Li}_{22} \mathrm{Sn}_{5}$ foil, metallic $\mathrm{Li}$ was electrochemically stripped away using a $\mathrm{Li} / \mathrm{Li}_{22} \mathrm{Sn}_{5} \mid \mathrm{Li}$ cell configuration. The sample for characterization was rinsed by dimethyl carbonate. In situ optical microscopy (Olympus, BX53M) observations of lithium metal electrodeposition on the $\mathrm{Li} / \mathrm{Li}_{22} \mathrm{Sn}_{5}$ and the pristine $\mathrm{Li}$ foil substrates were carried out using a side-by-side-type cell (EC-CELL, ECC-Opto-SBS). The Li metal counter and reference electrodes and GFF separator were assembled in an argonfilled glove box with less than $1 \mathrm{ppm}$ of oxygen and moisture. The monitoring of the Li metal was performed by a BioLogic SP-300.

Electrochemical measurements. 2032 coin-type cells were assembled in an Arfilled glove box for electrochemical measurements. The electrolyte was $1 \mathrm{M}$ lithium hexafluorophosphate $\left(\mathrm{LiPF}_{6}\right)$ in 1:1:1 ethylene carbonate (EC)/propylene carbonate (PC)/diethyl carbonate (DEC) with $10 \%$ fluoroethylene carbonate (FEC) and $1 \%$ vinylene carbonate (VC). Celgard $2300(19 \mu \mathrm{m}, \mathrm{PP} / \mathrm{PE} / \mathrm{PP})$ was used as the separator. Battery performance was investigated in a galvanostatic mode at various current densities using a LAND battery tester. The electrochemical impedance spectroscopy (EIS) measurement was performed on a Biologic VMP3 system. The NCM and LFP electrodes were fabricated with $80 \%$ active materials, $10 \%$ polyvinylidene fluoride (PVDF) and 10\% carbon black. The active mass loadings of NCM and LFP electrodes were $\sim 6.5$ and $\sim 5.0 \mathrm{mg} \mathrm{cm}^{-2}$, respectively. The current rates for NCM and LFP are based on their practical specific capacities of $170 \mathrm{mAh} \mathrm{g}^{-1}$ and $160 \mathrm{mAh} \mathrm{g}^{-1}$, respectively. For full cell measurement with high mass loading, the active mass loading of NCM electrode was $\sim 23.7 \mathrm{mg} \mathrm{cm}^{-2}$.

\section{Data availability}

The data that support the plots within this paper and other finding of this study are available from the corresponding author upon reasonable request.

Received: 9 April 2019; Accepted: 2 January 2020;

Published online: 11 February 2020

\section{References}

1. Armand, M. \& Tarascon, J.-M. Building better batteries. Nature 451, 652-657 (2008).

2. Scrosati, B. \& Garche, J. Lithium batteries: status, prospects and future. J. Power Sources 195, 2419-2430 (2010).

3. Manthiram, A. An outlook on lithium ion battery technology. ACS Centr. Sci. 3, 1063-1069 (2017).

4. Goodenough, J. B. \& Park, K.-S. The Li-ion rechargeable battery: a perspective. J. Am. Chem. Soc. 135, 1167-1176 (2013).

5. Whittingham, M. S. Ultimate limits to intercalation reactions for lithium batteries. Chem. Rev. 114, 11414-11443 (2014).

6. Sun, Y., Liu, N. \& Cui, Y. Promises and challenges of nanomaterials for lithium-based rechargeable batteries. Nat. Energy 1, 16071 (2016).

7. Dunn, B., Kamath, H. \& Tarascon, J.-M. Electrical energy storage for the grid: a battery of choices. Science 334, 928-935 (2011)

8. Goriparti, S. et al. Review on recent progress of nanostructured anode materials for Li-ion batteries. J. Power Sources 257, 421-443 (2014)

9. Lin, D., Liu, Y. \& Cui, Y. Reviving the lithium metal anode for high-energy batteries. Nat. Nanotechnol. 12, 194-206 (2017).

10. Cheng, X.-B., Zhang, R., Zhao, C.-Z. \& Zhang, Q. Toward safe lithium metal anode in rechargeable batteries: a review. Chem. Rev. 117, 10403-10473 (2017).

11. Lu, J., Chen, Z., Pan, F., Cui, Y. \& Amine, K. High-performance anode materials for rechargeable lithium-ion batteries. Electrochem. Energy Rev. 1, 35-53 (2018).

12. Albertus, P., Babinec, S., Litzelman, S. \& Newman, A. Status and challenges in enabling the lithium metal electrode for high-energy and low-cost rechargeable batteries. Nat. Energy 3, 16-21 (2018).

13. Liu, J. et al. Pathways for practical high-energy long-cycling lithium metal batteries. Nat. Energy 4, 180-186 (2019).

14. $\mathrm{Xu}, \mathrm{W}$. et al. Lithium metal anodes for rechargeable batteries. Energy Environ. Sci. 7, 513-537 (2014).

15. Lu, Y., Tu, Z. \& Archer, L. A. Stable lithium electrodeposition in liquid and nanoporous solid electrolytes. Nat. Mater. 13, 961-969 (2014).

16. Mogi, R. et al. Effects of some organic additives on lithium deposition in propylene carbonate. J. Electrochem. Soc. 149, A1578-A1583 (2002).
17. Ding, F. et al. Dendrite-free lithium deposition via self-healing electrostatic shield mechanism. J. Am. Chem. Soc. 135, 4450-4456 (2013).

18. Fan, X. et al. Non-flammable electrolyte enables Li-metal batteries with aggressive cathode chemistries. Nat. Nanotechnol. 13, 715-722 (2018).

19. Suo, L., Hu, Y.-S., Li, H., Armand, M. \& Chen, L. A new class of solvent-in-salt electrolyte for high-energy rechargeable metallic lithium batteries. Nat. Commun. 4, 1481 (2013).

20. Jiao, S. et al. Stable cycling of high-voltage lithium metal batteries in ether electrolytes. Nat. Energy 3, 739-746 (2018).

21. Li, N. W., Yin, Y. X., Yang, C. P. \& Guo, Y. G. An artificial solid electrolyte interphase layer for stable lithium metal anodes. Adv. Mater. 28, 1853-1858 (2015).

22. Kim, M. et al. Langmuir-Blodgett artificial solid-electrolyte interphases for practical lithium metal batteries. Nat. Energy 3, 889-898 (2018).

23. Zheng, G. et al. Interconnected hollow carbon nanospheres for stable lithium metal anodes. Nat. Nanotechnol. 9, 618-623 (2014).

24. Cha, E. et al. 2D MoS2 as an efficient protective layer for lithium metal anodes in high-performance Li-S batteries. Nat. Nanotechnol. 13, 337-344 (2018).

25. Liang, X. et al. A facile surface chemistry route to a stabilized lithium metal anode. Nat. Energy 2, 17119 (2017).

26. Tu, Z. et al. Fast ion transport at solid-solid interfaces in hybrid battery anodes. Nat. Energy 3, 310-316 (2018).

27. Han, X. et al. Negating interfacial impedance in garnet-based solid-state Li metal batteries. Nat. Mater. 16, 572-579 (2017).

28. Croce, F., Appetecchi, G., Persi, L. \& Scrosati, B. Nanocomposite polymer electrolytes for lithium batteries. Nature 394, 456-458 (1998).

29. Lin, D. et al. Layered reduced graphene oxide with nanoscale interlayer gaps as a stable host for lithium metal anodes. Nat. Nanotechnol. 11, 626-632 (2016)

30. Zhang, R. et al. Conductive nanostructured scaffolds render low local current density to inhibit lithium dendrite growth. Adv. Mater. 28, 2155-2162 (2016).

31. Wang, H., Lin, D., Liu, Y., Li, Y. \& Cui, Y. Ultrahigh-current density anodes with interconnected Li metal reservoir through overlithiation of mesoporous $\mathrm{AlF}_{3}$ framework. Sci. Adv. 3, 1701301 (2017).

32. Go, W. et al. Nanocrevasse-rich carbon fibers for stable lithium and sodium metal anodes. Nano Lett. 19, 1504-1511 (2019).

33. Yang, C.-P., Yin, Y.-X., Zhang, S.-F., Li, N.-W. \& Guo, Y.-G. Accommodating lithium into 3D current collectors with a submicron skeleton towards long-life lithium metal anodes. Nat. Commun. 6, 8058 (2015).

34. Tang, Y., Zhang, Y., Li, W., Ma, B. \& Chen, X. Rational material design for ultrafast rechargeable lithium-ion batteries. Chem. Soc. Rev. 44, 5926-5940 (2015).

35. Shi, Z., Liu, M. \& Gole, J. Electrochemical properties of Li-Zn alloy electrodes prepared by kinetically controlled vapor deposition for lithium batteries. Electrochem. Solid-State Lett. 3, 312-315 (2000).

36. Kudo, M. Solid state lithium battery. US4645726 (1987).

37. Hiratani, M., Miyauchi, K. \& Kudo, T. Effect of a lithium alloy layer inserted between a lithium anode and a solid electrolyte. Solid State Ion. 28-30, 1406-1410 (1998).

38. Kanno, R. \& Murayama, M. Lithium ionic conductor thio-LISICON: The $\mathrm{Li}_{2} \mathrm{SGeS}_{2} \mathrm{P}_{2} \mathrm{~S}_{5}$ system. J. Electrochem. Soc. 148, A742-A746 (2001).

39. Shek, M. L., Hebek, J., Sham, T. K. \& Xu, G. Q. A soft X-ray study of the interaction of oxygen with lithium. Surf. Sci. 234, 324 (1990).

40. Kover, L. et al. Electronic structure of tin oxides: high-resolution study of XPS and Auger spectra Surf. Interface Anal. 23, 461-466 (1995).

41. Huggins, R. Polyphase alloys as rechargeable electrodes in advanced battery systems. J. Power Sources 22, 341-350 (1988).

42. Lu, D. et al. Failure mechanism for fast-charged lithium metal batteries with liquid electrolytes. Adv. Energy Mater. 5, 1400993 (2015).

43. Wang, C. et al. Universal soldering of lithium and sodium alloys on various substrates for batteries. Adv. Energy Mater. 8, 1701963 (2018).

44. Liang, Z. et al. Composite lithium metal anode by melt infusion of lithium into a 3D conducting scaffold with lithiophilic coating. Proc. Natl Acad. Sci. 113, 2862-2867 (2016).

45. Chi, S.-S., Liu, Y., Song, W.-L., Fan, L.-Z. \& Zhang, Q. Prestoring lithium into stable 3D nickel foam host as dendrite-free lithium metal anode. Adv. Funct. Mater. 27, 1700348 (2017).

\section{Acknowledgements}

Y.S. acknowledges the support from the Natural Science Foundation of China (grant no. 51802105). Y.C. acknowledges support from the Assistant Secretary for Energy Efficiency and Renewable Energy, Office of Vehicle Technologies of the U.S. Department of Energy under the Extreme Fast Charging (XFC) program. H.L. acknowledges the support from the Technology Development Program to Solve Climate Changes (2018M1A2A2063341) through the National Research Foundation of Korea funded by the Ministry of Science and ICT \& Future Planning. The authors thank the Analytical and Testing Center of HUST and the Center for Nanoscale Characterization \& Devices (CNCD), WNLO of HUST for XRD and SEM measurements. 


\section{Author contributions}

Y.S. and Y.C. conceived and designed the experiments. M.W. performed materials fabrication, characterization and electrochemical measurements. S.K. conducted in situ optical microscopy observations of lithium metal electrodeposition. L.W., H.L. and G.W.Z. provided important experimental insights. M.W., Y.S. and Y.C. co-wrote the paper. All authors discussed the results and commented on the manuscript.

\section{Competing interests}

The authors declare no competing interests.

\section{Additional information}

Supplementary information is available for this paper at https://doi.org/10.1038/s41467020-14550-3.

Correspondence and requests for materials should be addressed to Y.C. or Y.S.

Peer review information Nature Communications thanks Lynden Archer, Hiroki Sakaguchi and the other, anonymous, reviewer(s) for their contribution to the peer review of this work.
Reprints and permission information is available at http://www.nature.com/reprints

Publisher's note Springer Nature remains neutral with regard to jurisdictional claims in published maps and institutional affiliations.

(c) Open Access This article is licensed under a Creative Commons Attribution 4.0 International License, which permits use, sharing, adaptation, distribution and reproduction in any medium or format, as long as you give appropriate credit to the original author(s) and the source, provide a link to the Creative Commons license, and indicate if changes were made. The images or other third party material in this article are included in the article's Creative Commons license, unless indicated otherwise in a credit line to the material. If material is not included in the article's Creative Commons license and your intended use is not permitted by statutory regulation or exceeds the permitted use, you will need to obtain permission directly from the copyright holder. To view a copy of this license, visit http://creativecommons.org/ licenses/by/4.0/.

(C) The Author(s) 2020 